\title{
Bioavailability of Tea Components
}

\author{
Alexander Yashin \\ Scientific Research Center "Chromatographia" \\ 12a Selskohozyaistvennaya Street, Moscow 129226, Russia
}

Tel: 7-499-181-1402Ｅ-mail: yashinchrom@mail.ru

Boris Nemzer (Corresponding author)

VDF FutureCeuticals, Inc.

2692 North State Rt. 1-17, Momence, IL 60954, USA

Tel: 1-815-507-1400Ｅ-mail: bnemzer@vandrunen.com

\author{
Yakov Yashin \\ Scientific Research Center "Chromatographia" \\ 12a Selskohozyaistvennaya Street, Moscow 129226, Russia \\ Tel: 7-499-181-1402Ｅ-mail: chromatograph@yandex.ru
}

Received: January 16, 2012

Accepted: February 2, 2012 Published: May 1, 2012

doi:10.5539/jfr.v1n2p281

URL: http://dx.doi.org/10.5539/jfr.v1n2p281

\begin{abstract}
This review discusses the bioavailability of active components of green and black teas--in hot brewed tea, cold tea, and dietary supplements containing tea extracts, based on literature published in 1995-2011. Many publications demonstrate that consumption of tea increases the antioxidant status of a person (between 3.5-76\%) and reduces the concentration of oxidative stress biomarkers in biological fluids. In 1-2 hours after tea intake, epigallocatechin gallate (EGCG), epicatechin (EC), and epicatechin gallate (ECG) at a level of 5-150 ng/ml were detected in plasma by HPLC. The results of pharmacokinetics and metabolism of biologically active tea components analyzed within 24 hours in plasma, urine, and feces by HPLC-MS and GC-MS are presented. Dozens of metabolites were identified in urine and plasma - these are methylated, sulfated, and glucuronide conjugates of catechins. Some metabolites were shown to have high antioxidant activity. The role of the small intestine and colon in absorption of catechins was also identified.
\end{abstract}

Keywords: Tea, Bioavailability, Polyphenols, Tea catechins, Antioxidants

\section{Introduction}

The biological activity of green tea and other teas is directly related to their bioavailability, therefore the bioavailability of tea is a primary parameter.

Bioavailability is typically estimated by measuring that portion of a drug (as a percentage) which reaches the systemic blood flow after its non-systemic administration.

In order to use tea components as effective antioxidant therapy, one needs first to know the content of polyphenol antioxidants in different varieties of tea, and, secondly, their bioavailability. It is well known that not all polyphenols are absorbed with equal efficiency. Antioxidants are extensively metabolized by liver enzymes.

Knowledge of polyphenol metabolic processes and bioavailability is needed to evaluate their biological activity in tissues. Knowledge about the bioavailability of antioxidants is also essential for understanding their effect of on human health.

Flavonoid aglycones (without sugar residues) can be absorbed in the small intestine. However, most flavonoids are present in foods as glycosides, esters, or polymers and they often cannot be absorbed in these forms. Before 
being absorbed, these flavonoids must be hydrolyzed by intestinal enzymes or gut flora. During absorption, polyphenols are conjugated first in the intestine and later in the liver. These reactions mainly include methylation, sulfation, and glucuronidation. Polyphenols are able to penetrate tissues (Holst \& Williamson, 2004).

Polyphenols and their derivatives are eliminated from the body in urine and bile.

The bioavailability of tea components, in particular catechins, may be determined by several methods:

- by the increase of the antioxidant activity (capacity) of plasma or human serum after consumption of tea or its individual components;

- by direct determination of catechins in biological fluids and tissues one or two hours after consuming a certain quantity of tea or individual catechins;

- by determining the effect of consumed tea and its components on reduction of oxidative stress markers.

Table 1 presents data related to increased antioxidant activity (AA) of human plasma after consumption of different quantities of tea.

Tea consumption reduces concentrations of oxidative stress biomarkers in biological fluids. The most well-known oxidative stress biomarkers are: 8-hydroxydeoxyguanosine (8-OHdG), tyrosine derivatives, malondialdehyde, $\mathrm{F}_{2}$-isoprostane, and phosphatidylcholine hydroperoxide $(\mathrm{PCOOH})$ - marker of oxidative injury of plasma lipoproteins (Miyazawa, 2000).

The consumption of $900 \mathrm{ml}$ of green tea per day for 7 days was shown to reduce 8 -OHdG in human urine by $40 \%$ and malondialdehyde by $80 \%$, while there were wide individual variations noted (Klaunig et al., 1999). Consumption of green tea reduced PCOOH concentrations in human plasma by 60\% (Nokagawa et al., 1999)

Increased consumption of green tea reduced the concentration of F2-isoprostane in humans and animals (Morrow et al., 1999).

An anticarcinogenic effect of green tea and its catechins has been observed in many studies (Yang et al., 2000). Especially strong results were obtained in animals.

Prolonged exposure to UV radiation promotes the formation of cyclobutane pyrimidine dimer (CPD) which plays an important role in skin carcinogenesis (Katiyar et al., 2001). If skin is treated with an EGCG solution $\left(1-4 \mathrm{mg} / \mathrm{cm}^{2}\right) 20 \mathrm{~min}$ before UV radiation, the formation of CPD is significantly reduced (Katiyar et al., 2000).

\section{Investigation of the Bioavailability of Tea Catechins}

Bioavailability and metabolism of some individual catechins such as epigallocatechin gallate (EGCG), epicatechin (EC), epigallocatechin (EGC) and epicatechin gallate (ECG) as well as total catechins of green and black tea in humans have been studied rather frequently (Stalmach et al., 2009; Daniele Del Rio et al., 2010; Sun et al., 2009; Henning et al., 2004; Chow et al., 2001; Higdon et al., 2003; Chow et al., 2005; Nakagawa et al., 2009; Crozier et al., 2009; Li et al., 2000; Meng et al., 2001; Auger et al., 2008; Stalmach et al., 2009; Spencer et al., 2003; Aura, 2008; Selma et al., 2009; Feng, 2006; Mulder et al., 2005; Dalluge \& Nelson, 2000; Lee et al., 2011; Lee et al., 2011; Ku et al., 2010; Lee et al., 2010; Roowi et al., 2010).

Bioavailability and metabolism processes of black tea theaflavins and thearubigins were studied significantly less (Mulder et al., 2001; Wiseman et al., 2001). High dose (700 mg) of mixed theaflavins was given two healthy volunteers, one male and one female. Only theaflavin was detected because enzyme treatment also removed ester gallate. Maximum theaflavin concentration detected in the plasma of the female and the male were 1.0 and $0.5 \mu \mathrm{g} / \mathrm{L}$, respectively, and maximum concentrations in urine were 0.6 and $4.2 \mu \mathrm{g} / \mathrm{L}$, respectively, all at 2 hours (Mulder et al., 2001).

The beneficial health effects of tea catechins are fundamentally related to their bioavailability, absorption, distribution in various organs, metabolism, and excretion from the body.

The bioavailability is estimated by the concentration of a particular catechin or its metabolites in a certain organ. It is impossible to accurately determine these parameters in vivo in humans due to the difficulty of accessing the organs; therefore, such studies are conducted on animals. However, the bioavailability and metabolism of catechins in humans and animals may vary. The absolute bioavailability is often estimated by the number of active compounds into the blood.

As already indicated, bioavailability consists of several interrelated processes: liberation, absorption, distribution, metabolism, and excretion (Holst \& Williamson, 2004). 
The absorption is hard to assess precisely. Sometimes it is judged by excretions in the urine. However, the total absorption cannot be assessed in this way because some catechins could be metabolized by the liver and conjugate in the intestines (Warden et al., 2001). Only about 1.7\% of consumed catechins are found in plasma, urine, and feces of a person who drinks black tea. Bioavailability of gallocatechins is lower than that of catechins without galloyl groups (Warden et al., 2001).

Catechins (EC, ECG, EGC, and EGCG) are relatively high molecular weight compounds (300-450) comprised of more than 5 hydroxyl groups. They have low bioavailability due to their large size (Lipinsi et al., 2001). The level of catechins and other flavonoids in plasma does not exceed $1 \mu \mathrm{M}$ when consumed in typical amounts (1-2 cups, 100-200 mg of catechins).

The total concentration of catechins (both free and conjugated) is about 2-3 $\mu \mathrm{M}$ or less (Yang et al., 1998). These plasma concentrations are much lower than those used in studies in vitro.

Various measurements, including HPLC, showed that the concentration of catechins in human plasma increases in 1-2 hours after tea consumption. But the bioavailability of tea catechins is relatively low-only $0.2-2 \%$ of the consumed amount of catechins gets into plasma of healthy humans (Wiseman et al., 2001). When green tea is consumed in high doses, the overall level of catechins in human plasma is about 0.6-1.8 $\mu \mathrm{M}$ (Holst \& Williamson, 2004).

In one study, the bioavailability of catechins (flavan-3-ols) after consumption of cold tea in sealed packages was investigated in 20 volunteers (Del Rio et al., 2010). After consumption, the urine of volunteers was analyzed over a 24 hour period by HPLC-electrospray MS/MS. Eight metabolites of flavan-3-ols and unmetabolized gallic acid were identified in urine. Urine contained $7.2 \%$ of flavan-3-ols and $4.5 \%$ of gallic acid in relation to their total amounts contained in the consumed tea. The maximum level of 5 metabolites (epicatechin sulfate, methyl-epicatechin sulfate, epicatechin glucuronide, epigallocatechin glucuronide, and methyl-epigallocatechin glucuronide) were observed in the urine 4 hours after consumption of cold tea; the maximum level of 2 metabolites (methyl-epigallocatechin and methyl-epigallocatechin sulfate) were present in the urine only after 10 hours; whereas the content of epigallocatechin in the urine was seen as constantly increasing over a period of 24 hours. Bioavailability observed in this study (Del Rio et al., 2010) was consistent with a previous study (Stalmach et al., 2008).

The bioavailability of pure EGC, ECG, and EGCG in healthy people was investigated. After consumption of 1.5 $\mathrm{mM}$ of EGC, ECG, and EGCG alone, the average plasma concentration was $5 \mu \mathrm{M}, 3.1 \mu \mathrm{M}$, and $1.3 \mu \mathrm{M}$ respectively (Van Hof, 1998). One large review (Sun et al., 2009) summarizes pharmacogenetic parameters of tea metabolites in human body after consumption. After oral consumption of 100 to $1600 \mathrm{mg}$ of pure epigallocatechin gallate, 0.26 to $6.35 \mu \mathrm{m}$ of epigallocatechin gallate was detected in plasma in 2-3 hours; some conjugated compounds of epigallocatechin gallate in the amount of 0.28 to $7.40 \mu \mathrm{m}$ were also found in 1.9 to 4.6 hours.

These data show that the bioavailability of various catechins varies greatly. EGCG is the least bioavailable. During absorption, catechins undergo intensive bioconversions, including methylation, sulfonation, etc (Meng et $a l$, 2002). It is assumed that about $80 \%$ of tea catechins in plasma and urine are in the form of their conjugates. Some conjugates have intact hydroxyl substituents, which can capture superoxide free radicals, and their antioxidant efficiency remains quite high (Kuhnie et al, 2000, Voidyanathon \& Walle, 2002, Li et al., 2001, Li et $a l ., 2000)$. Even having low bioavailability, tea catechins have a salutary effect in many diseases.

Table 2 provides a list of studies which determined the catechin content in different biological fluids and tissues of humans and animals. Table 3 shows specific examples of bioavailability of green tea, black tea, and tea catechins separately.

The evidence for antioxidant effects of tea demonstrated in clinical trials is summarized in one review (Manach et al., 2004). The authors have come to the unequivocal conclusion that flavonoids-tea antioxidants-are absorbed in the intestine, which leads to a significant increase in antioxidant capacity of human plasma an hour after tea consumption.

In one study, it is assumed that part of the catechins is present in a metabolized form (Natsume et al., 2003). In particular, dimerization of EGCG in an alkaline medium results in new compounds (theasinensins A and D) which antioxidant activity is 2-3 times greater.

In another study, an improved HPLC method with a coulometric detector was proposed for the polyphenols of green and black tea in different biomatrixes (plasma, urine, saliva, and tissues) (Pietta et al., 1998). 
Polyphenols were extracted with ethyl acetate. Major catechins, theaflavins, and catechin metabolites were identified by HPLC.

The catechins were determined in plasma, saliva, and urine. Tissue samples for the determination of catechins in tissues were taken from rats.

Approximately $180 \mathrm{ng} / \mathrm{ml}$ of EGCG, 156-158 ng/ml of EGC, $68-70 \mathrm{ng} / \mathrm{ml}$ of EC, and $85-87 \mathrm{ng} / \mathrm{ml}$ of ECG were detected in plasma ( $\left.\mathrm{ng}=-1 \cdot 10^{-9} \mathrm{~g}\right)$. The detection limit was at $5-10 \mathrm{ng} / \mathrm{ml}$.

The proposed method gives reproducible and reliable results in determining the eight major polyphenols at the same time.

The bioavailability of green tea and its individual catechins was investigated in several studies (Table 3) (Nokagawa et al., 1999, Clifford et al., 2000, Manach et al., 2004).

In example number 4, $6 \mathrm{mg}$ of EGCG was detected in the entire blood by HPLC upon consumption of $82 \mathrm{mg}$, which is less than $7 \%$ of the consumed amount.

\section{Metabolism and Pharmacokinetics of the Biologically Active Tea Components.}

Catechin metabolites (e.g., EC, ECG, EGC, and EGCG) were determined in humans after oral intake of green tea (Pietta et al., 1998a, Pietta et al., 1998b, Mudler et al., 2005, Yoshino et al., 1999, Stalmach et al., 2009).

In human plasma, the portion of the methylated EGC is higher than that of ECG and EGCG (Ho et al., 1995).

In human plasma, a greater amount of EGCG is present in the free form than EGC and EC which are mostly in the conjugated form (Meng et al., 2002, Umegaki et al., 2001, Kotani et al., 2003). In one hour after drinking tea, $77 \%$ of EGCG was in the free form in human plasma, whereas the result was $31 \%$ and $21 \%$ of EGC and EC respectively (Meng et al., 2002). After consuming a tea supplement and pure catechin, over $80 \%$ of catechin found in plasma was in the bound form. EGC has not been detected at all, whereas $57-71 \%$ of ECG was present in the glucuronidated form, $23-36 \%$ in the sulfonated form, and 3-13\% in the free form. In urine, over $90 \%$ of EGC was in the sulfonated form (Unno et al., 2005).

The catechins which are not absorbed in the small intestine, reach the large intestine which contains trillions of microorganisms. Bacterial enzymes degrade polyphenols to simpler molecules, in particular to oxyaromatic acids. Then these products of microbial metabolism are absorbed. Some of these metabolites were identified ( $\mathrm{Li}$ et al., 2000).

Absorption, metabolism, and excretion in urine of green tea flavonols were studied by HPLC-MS in 10 healthy volunteers who were taking $500 \mathrm{ml}$ of Choladi green tea (Choladi, India), containing $648 \mu \mathrm{mol}$ of flavan-3-ols (Stalmach et al., 2009). After consumption of green tea, plasma and urine were analyzed over a 24 hour period. Ten metabolites of O-methylated, sulfated, and glucuronide conjugates of epicatechin and epigallocatechin at a concentration of 29-126 nM were found to occur 1.6-2.3 hours after ingestion. This proves that absorption occurs in the small intestine. Plasma also contained unmetabolised epigallocatechin gallate and epicatechin gallate at concentrations of 55 and $25 \mathrm{nM}$, respectively. Fifteen metabolites of epicatechin and epigallocatechin were identified in urine. No metabolites of epigallocatechin gallate and epicatechin gallate were detected. Overall flavanol excretion was estimated at $8.1 \%$ of intake but excretion of certain flavanols varied from $11.4 \%$ to $28.5 \%$ of intake. These studies have shown that epicatechins are more bioavailable than other catechins in green tea.

Hippuric acid is the main metabolite when black tea is consumed (Tsuchiya et al., 1997, Yang et al., 2000). Hippuric acid was also detected in urine when green tea was consumed (Tsuchiya et al., 1997). After consumption of black tea, 1,3-dihydroxyphenyl-2-0-sulfate was identified as a metabolite (Yang, 2000). Extremely low levels of theaflavins were detected in human plasma and urine after consumption of black tea (Clifford et al., 2000).

One study claims that about $43 \%$ of tea polyphenols is metabolized to hippuric acid (Masukawa et al., 2006). It has been suggested that thearubigins also are degraded to hippuric acid (Tsuchiya et al., 1997). But hippuric acid can also be derived from aromatic amino acids. That is why 3-hydroxyhippuric acid is considered as the best biomarker for tea consumption (Rechner et al., 2001).

In one study (Lee et al., 2010), catabolites in urine and feces were investigated by GC-MS in patients with a functioning colon and in patients without a colon. In the first group of patients, the following components were detected in the urine within 24 hours: pyrocatechin, pyrogallol, 4-hydroxybenzoic acid, 4-hydroxyphenylacetic acid, 3-methoxy-4-hydroxy-phenylacetic acid, and hippuric acid. In patients without a colon, only hippuric acid and 4-hydroxyphenylacetic acid were found in small amounts. The above acids were detected in feces 24 hours later. 
Only very few studies related to the determination of the tea components in human tissues were published. In one study, the bioavailability of both green and black tea polyphenols was investigated by their content in human prostate tissue samples (Kim et al., 2000). The content of both free and conjugated EGC and EGCG in these tissues was significantly higher in people who consumed tea than in people who consumed an aqueous solution of caffeine.

Tea metabolites are primarily excreted through the urine, and highly conjugated tea components through the bile (Manach et al., 2004). The half-life of tea catechins in the body is approximately 2-3 hours. EGCG is excreted more slowly (Manach et al., 2004).

In one study it was shown that the bioavailability of tea polyphenols in tea dietary supplement capsules is much higher than after consumption of green and black tea (Serafini et al., 2000). This fact requires further research. The effect of food matrix on the bioavailability has not yet been investigated.

It is crucial to evaluate the bioactivity the glucuronidated, sulfated, and methylated derivatives of catechins (metabolites) to establish a link between tea consumption and cancer risk (Nokagawa et al., 1999).

Once absorbed, the tea catechins are metabolized by glucuronidation, methylation, and sulfonation converting the catechins into more hydrophilic compounds (Yang et al., 1998 \& Van Hof, 1998). Metabolic reactions are catalyzed by enzymes.

Only a very small amount of conjugated catechins are present in plasma. Prior to determining the catechin metabolites in plasma and urine samples by HPLC, they must be pre-treated with $\beta$-glucuronidase and sulphatase in order to remove the respective functional groups.

The main metabolite which was identified in plasma is 4'-methyl-EGC. In 2 hours after consumption of green tea, the amount of 4'-methyl-EGC present in human plasma is 4-6 times greater than EGC (Yang et al., 1998). Approximately $90 \%$ of 4'-0-methyl-EGC is excreted via the urine within 8 hours.

The EGCG metabolites, 4', 4"-di-0-methyl-EGCG, were identified in human plasma and urine after tea consumption using LC/MS/MS (Meng et al., 2002).

The enzymes catalyze many reactions in small and large intestines, including decomposition of the flavonoids down to oxyaromatic acids. These compounds are also antioxidants and have a beneficial physiological effect. Unfortunately, very few studies were conducted to these metabolites.

In one study, the bioavailability and pharmacokinetics of catechins in the blood and urine after consumption of green and black tea, as well as green tea dietary supplements, was investigated in 30 volunteers. The content of catechins (EC, ECG, EGC, and EGCG) in the original beverages was determined by HPLC with coulometric detector.

The total amount of EC, ECG, EGC, and EGCG in the green and black tea drinks and in tea dietary supplements was $679.0 \pm 9.4,496.5 \pm 3.3$ and $386 \pm 3.2 \mathrm{mg}$ respectively. Indian Darjeeling tea which contains a large amount of EGCG (on a level with green tea), was used for black tea. After catechin-containing drink consumption, total catechin content in plasma was measured in 30 healthy volunteers within eight hours. The highest content in plasma was 1-2 hours after the drinks were taken, and then the concentration of catechins slowly decreased to the initial zero value.

The greatest value of the total content of catechins in plasma, $1.2 \mu \mathrm{M} / \mathrm{L}$, was reached after consumption of green tea. The maximum plasma concentration after consumption of black tea and dietary supplements was approximately $0.5 \mu \mathrm{M} / 1$.

As was found previously, tea catechins are largely metabolized or broken down into simpler phenolic acids, such as 4-hydroxybenzoic, 3,4-dihydroxybenzoic, and 3-methoxy-4-hydroxyhippuric acids ${ }^{48}$. These acids also showed in vitro antioxidant activity. As noted above, EGCG is dimerized in an alkaline medium resulting in new compounds, theasinensins $\mathrm{A}$ and $\mathrm{D}$, which have higher antioxidant activity than EGCG.

Influence of joint consumption of epigallocatechin gallate and caffeine on their absorption and metabolism in humans was also explored (Kiyotaka et al., 2009). Caffeine reduces sulfonation and glucuronidation of epigallocatechin gallate. A metabolomic analysis of green tea was carried out by nuclear magnetic resonance (NMR) followed by chemometrics (Mulder et al., 2005). 


\section{Conclusion}

It can be concluded that when green tea is consumed orally, the tea catechins reach human plasma at the micromolar level (less than 1-2\%). The metabolites of tea components are present in plasma to a greater extent, and they also show antioxidant activity and can protect people from various diseases.

However, the bioavailability of tea catechins was not sufficiently investigated. In order to assess the biological activity of tea components in vivo, various tea metabolites must be thoroughly studied and identified, and their antioxidant and other properties must be assessed.

Detailed study of the tea components' pharmacokinetic processes, such as absorption process, duration of their presence in the body, and excretion time, is also necessary.

It is absolutely necessary in order to be able to reasonably determine the optimal frequency of tea consumption in order to maintain a constant concentration of its biologically active components in human plasma during antioxidant therapy aimed at combating various diseases.

\section{References}

Auger, C., Hara, Y., \& Crozier, A. (2008). Bioavailability of polyphenon E flavan-3-ols in humans with an ileostomy. Journal of Nutrition, 138, 1535S-1542S.

Aura, A. M. (2008). Microbial metabolism of dietary phenolic compounds in the colon. Phytochemistry Reviews, 7(3), 407-429. http://dx.doi.org/10.1007/s11101-008-9095-3

Benzie, I. F., Szeto, Y. T., Strain, J. J., \& Tomlinson, B. (1999). Consumption of green tea causes rapid increase in plasma antioxidant power in humans. Nutrition and Cancer, 34, 83-87. http://dx.doi.org/10.1207/S15327914NC340112

Chow, H. H, Hakim, I. A, Vining, D. R, Crowell, J., Ranger-Moore, J., Chew, W., Celaya, C., Rodney, S., Hara, Y., \& Alberts, D. (2005). Effects of dosing condition on the oral bioavailability of green tea catechins after single-dose administration of polyphenon E in healthy individuals. Clinical Cancer Research, 11(12), 4627-4633. http://dx.doi.org/10.1158/1078-0432.CCR-04-2549.

Chow, H. H., Cai, Y., Alberts, D., Hakim, I., Dorr, R., Shahi, F., Crowell, J. A., Yang, C. S., \& Hara, Y. (2001). Phase I pharmacokinetic study of tea polyphenols following single-dose administration of epigallocatechin gallate and polyphenon E. Cancer Epidemiology, Biomarkers \& Prevention, 10(1), 53-58

Clifford, M. N., Coleland, E. L., Bloxsidge, J. P., \& Mitchell, L. A. (2000). Hippuric acid as a major excretion Product Associated with Black Tea Consumption. Xenobiotica, 30(3), 317-326.

Crozier, A., Jaganath, I. B., \& Clifford, M. N. (2009). Dietary phenolics: chemistry, bioavailability and effects on health. Natural Product Reports, 26, 1001-1043. http://dx.doi.org/10.1039/B802662A.

Dalluge, J., \& Nelson, B. (2000). Determination of tea catechins. Journal of Chromatography A, 881(1-2), 411-424. http://dx.doi.org/10.1016/S0021-9673(00)00062-5

Del Rio, D., Stalmach, A., Calani, L., \& Crozier, A. (2010). Bioavailability of Coffee Chlorogenic Acids and Green Tea Flavan-3-ols. Nutrients, 2(8), 820-833. http://dx.doi.org/10.3390/nu2080820

El-Hady, D., \& El-Maali, N. (2008). Determination of catechin isomers in human plasma subsequent to green tea ingestion using capillary electrophoresis with a high-sensitivity cell. Talanta, 76(1), 138-145. http://dx.doi.org/10.1016/j.talanta.2008.02.026

Feng, W. Y. (2006). Metabolism of green tea catechins: an overview. Current Drug Metabolism, 7(7), 755-809.

Henning, S. A., Aronson, W., Niu, Y., et al. (2006). Tea Polyphenols and theaflavins are present in prostate tissue of humans and mice after green and black tea consumption. Journal of Nutrition, 136, 1839-1843.

Henning, S., Niu, Y., Lee, N., Thames, G., Minutti, R., Wang, H., Go, V., \& Heber, D. (2004). Bioavailability and antioxidant activity of tea flavanols after consumption of green tea, black tea, or a green tea extract supplement. The American Journal of Clinical Nutrition, 80(6), 1558-1564.

Higdon, J. V., \& Frei, B. (2003). Tea catechins and polyphenols: health effects, metabolism, and antioxidant functions. Critical Reviews in Food Science and Nutrition, 43(1), 89-143. http://dx.doi.org/10.1080/10408690390826464

Ho Y., Lee Y. L., \& Hsu K. Y. (1995). Determination of (+)-catechins in plasma by high-performance liquid chromatography using fluorescence detection. Journal of Chromatography B, 383(2), 383-389, http://dx.doi.org/10.1016/0378-4347(94)00535-D 
Holst, B., \& Williamson, G. (2004). Methods to Study Bioavailability of Phytochemicals. Phytochemicals in Health and Disease. Ed. R. Fenwick, New York: Marcel Dekker. http://dx.doi.org/10.2174/138920006778520552

Katiyar, S. K., \& Elmets, C. A. (2001). Green tea polyphenolic antioxidants and skin photoprotection (review). International Journal of Oncology, 18, 1307-1313.

Katiyar, S. K., Perez, A., \& Mukhtar, H. (2000). Green tea polyphenol treatment to human skin prevents formation of ultraviolet light B-induced pyrimidine dimmers in DNA. Clinical Cancer Research, 6, 3864-3869

Kim, S., Lee, M. J., Hong, J., Li, C., Smith, T., Yang, G., Seril, D., \& Yang, C. (2000). Plasma and tissue levels of tea catechins in rats and mice during chronic consumption of green tea polyphenols. Nutrition and Cancer, 37, 41-48. http://dx.doi.org/10.1207/S15327914NC3701_5

Kivits, G. A., van der Sman, F. J. P., \& Tijburg, L. B. M. (1997). Analysis of catechins from green and black tea in humans. International Journal of Food Science and Nutrition, 48(6), 387-392.

Klaunig, J. E., Xu, Y., Han, C., Kamendulis, L., Chen, J., Heiser, C., Gordon, M., \& Mohler III, E. (1999). The effect of tea consumption on oxidative stress in smokers and nonsmokers. Proceedings of the Society for Experimental Biology and Medicine, 220(4), 249-254. http://dx.doi.org/10.3181/00379727-220-44375

Kotani, A., Miyashita, N., \& Kusu, F. (2003). Determination of catechins in human plasma after commercial canned green tea ingestion by high-performance liquid chromatography with electrochemical detection using a $\begin{array}{lllll}\text { microbore column. Journal of Chromatography } & \text { B, 25(2), 269-275. }\end{array}$ http://dx.doi.org/10.1016/S1570-0232(02)01036-X

Ku, K. M., Choi, J. N., Kim, J., Kim, J. K., Yoo, L. G., Lee, S. J., Hong, Y. S., \& Lee, C. H. (2010). Metabolomics analysis reveals the compositional differences of shade grown tea (Camellia sinensis L.). Journal of Agriculture and Food Chemistry, 58(1), 418-426. http://dx.doi.org/10.1021/jf902929h

Kuhnie, G., Spencer, J., Schroeter, H., Shenoy, B., Debman, E., Srai, S., Rice-Evans, C., \& Hahn, U. (2000). Epicatechin and catechin are O-methylated and glucuronidated in the small intestine. Biochemical and Biophysical Research Communications, 277(2), 507-512. http://dx.doi.org/10.1006/bbrc.2000.3701

Lee, H. C., Jenner, A. M., Low, C. S., \& Lee, Y. K. (2006). Effect of tea phenolics and their aromatic fecal bacterial metabolites on intestinal microflora. Research in Microbiology, 157(9), 876-884. http://dx.doi.org/10.1016/j.resmic.2006.07.004.

Lee, J. E., Lee, B. J., Chung, J. O., Hwang, J. A., Lee, S. J., Lee, C. H., \& Hong, Y. S. (2010). Geographical and climatic dependencies of green tea (Camellia sinesis) metabolites: A 1H NMR-based metabolomics study. Journal of Agriculture and Food Chemistry, 58(19), 10582-10589. http://dx.doi.org/10.1021/jf102415m.

Lee, J. E., Lee, B., Chung, J. O., Shin, H. J., Lee, S. J., Lee, C. H., \& Hong, Y. S. (2011). 1H NMR-based metabolomics characterization of green tea (Camellia sinensis) during fermentation. Food Research International, 44, 597-604. http://dx.doi.org/10.1016/j.foodres.2010.12.004.

Lee, J. E., Lee, B. J., Hwang, J., Ko, K. S., Chung, J. O., Kim, E. H., Lee, S. J., \& Hong, Y. S. (2011). Metabolic Dependence of Green Tea on Plucking Positions Revisited: A Metabolomic Study. Journal of Agriculture and Food Chemistry, 59(19), 10579-10585. http://dx.doi.org/10.1021/jf202304z

Li, C., Lee, M. J., Sheng, S. M., Meng, X., Prabhu, S., Winnik, B., Huang, B., Chung, J., Yan, S., Ho, C-T., \& Yang, C. (2000). Structural identification of two metabolites of catechins and their kinetics in human urine and blood after tea ingestion. Chemical Research in Toxicology, 13(3), 177-184. http://dx.doi.org/10.1021/tx9901837

Li, C., Meng, X., Winnik, B., Lee, M-J., Lu, H., Sheng, S., Buckley, B., \& Yang, C. (2001). Analysis of urinary metabolites of tea catechins by liquid chromatography/electrospray ionization mass spectrometry. Chemical Research in Toxicology, 14(6), 702-707. http://dx.doi.org/10.1021/tx0002536

Lipinski, C. A., Lombardo, F., Dominy, B. W., \& Feeney, P. J. (1997). Experimental and computational approaches to estimate solubility and permeability of drug discovery and development settings. Advanced Drug Delivery Reviews, 23, p. 3-25. http://dx.doi.org/10.1016/S0169-409X(96)00423-1

Longley-Evans, S. C. (2000). Consumption of black tea elicits an increase in plasma antioxidant potential in humans. International Journal of Food Sciences and Nutrition, 51(5), 309-315. http://dx.doi.org/10.1080/096374800426902

Manach, C., Sealbert, A., Morand, C., Reemesy, C., \& Jimenez, L. (2004). Polyphenols: food sources and bioavailability. The American Journal of Clinical Nutrition, 79(5), 727-747. 
Manach, C., Williamson, G., Morand, C., Scalbert, A., \& Remesy, C. (2005). Bioavailability and bioefficacy of polyphenols in humans. I. Review of 97 bioavailability studies. The American Journal of Clinical Nutrition, 81(1), 2305-2425

Masukawa, Y., Matsui, Y., Shimizu, N., Kondou N., Endou, H., Kuzukawa, M., \& Hase, T. (2006). Determination of green tea catechins in human plasma using chromatography-electrospray ionization mass spectrometry. Journal of Chromatography B, 834(1-2), 26-34. http://dx.doi.org/10.1016/j.jchromb.2006.02.008

Meng, X., Lee, M. J., Li, C., Sheng, S., Zhu, N. Q., Sang, S. N., Ho, C. T., \& Yang, C. S. (2001). Formation and identification of 4'-O-methyl-(-)-epigallocatechin in humans. Drug Metabolism \& Disposition, 29(6), 789-793

Meng, X., Sang, S., Zhu, N., Lu, H., Sheng, S., Lee, M-J., Ho, C-T., \& Yang, C. (2002). Identification and characterization of methylated and ring-fission metabolites of tea catechins formed in humans, mice, and rats. Chemical Research in Toxicology, 15(8), 1042-1050. http://dx.doi.org/10.1021/tx010184a

Miyazawa, T. (2000). Absorption, metabolism and antioxidative effects of tea catechin in humans. BioFactors, $13,55-59$

Morrow, J. D., Chen, Y., Brame, C. J., Yang, J., Sanchez, S., Xu, J., Zackert, W., Awad, J., \& Roberts, L. J. (1999). The Isoprostanes: unique prostaglandin-like products of free-radical-initiated lipid peroxidation. Drug Metabolism Reviews, 31(1), 117-139. http://dx.doi.org/10.1081/DMR-100101910

Mulder, T. P., Rietveld, A., \& van Amelsvoort, J. (2005). Consumption of both black tea and green tea results in an increase in the excretion of hippuric acid into urine. The American Journal of Clinical Nutrition, 81(1), 256S-260S.

Mulder, T. P., van Platerink, C., Wijnand Schuyl, P., \& van Amelsvoort, J. (2001). Analysis of theaflavins in biological fluids using liquid chromatography-electrospray mass spectrometry. Journal of Chromatography B: Biomedical Sciences and Applications, 760(2), 271-279. http://dx.doi.org/10.1016/S0378-4347(01)00285-7

Nakagawa, K., Nakayama, K., Nakamura, M., Sookwong, P., Tsuduki, T., Nuno, H., Kimura, F., \& Miyazawa, T. (2009). Effects of co-administration of tea epigallocatechin-3-gallate (EGCG) and caffeine on absorption and metabolism of EGCG in humans. Bioscience, Biotechnology, and Biochemistry, 73(9), 2014-2017. http://dx.doi.org/10.1271/bbb.90195

Natsume, M., Osakabe, N., Oyama, M., Sakasi, M., Baba, S., Nakamura, Y., Osawa, T., \& Terao, J. (2003). Structures of (-)-epicatechin glucuronide identified from plasma and urine after oral ingestion of (-)-epicatechin: differences between human and rat. Free Radical Biology and Medicine, 34(7), 840-849. http://dx.doi.org/10.1016/S0891-5849(02)01434-X

Nokagawa, K., Ninomiya, M., Okubo, T., Aoi, N., Juneja, L., Kim, M., Yamanaka, K., \& Miyazama, T. (1999). Tea catechin supplementation increases antioxidant capacity and prevents phospholipids hydroperoxidation in plasma of humans. Journal of Agricalture and Food Chemistry, 47(10), 3967-3973. http://dx.doi.org/10.1021/jf9811951

Pietta, P. G., Simonetti, P., Gardana, C., Brusamolino, A., Morazzoni, P., \& Bombardelli, E. (1998a). Catechin metabolites after ingestion of green tea infusions. BioFactors, 8(1-2), 111-118. http://dx.doi.org/10.1002/biof.5520080119

Pietta, P. G., Simonetti, P., Gardana, C., Brusamolino, A., Morazzoni, P., \& Bombardelli, E. (1998b). Relationship between rate and extent of catechin absorption and plasma antioxidant status. International Union of Biochemistry and Molecular Biology, 46(5), 895-903. http://dx.doi.org/10.1080/15216549800204442

Rechner A. R., Spencer, J., \& Kuhnle, G. (2001). Novel biomarkers of the metabolism of caffeic acid derivatives in vivo. Free Radical Biology and Medicine, 30(11), 1213-1222. http://dx.doi.org/10.1016/S0891-5849(01)00506-8

Roowi, S., Stalmach, A., Mullen. W., Lean, M., Edwards, C., \& Crozier, A. (2010). Green tea flavan-3-ols: colonic degradation and urinary excretion of catabolites by humans. Journal of Agriculture and Food Chemistry, 58(2), 1296-1304. http://dx.doi.org/10.1021/jf9032975.

Selma, M. V., Espin, J. C., \& Tomas-Barber, F. (2009). Interaction between phenolics and gut microbiota: role in human health. Journal of Agriculture and Food Chemistry, 57(15), 6485-6501. http://dx.doi.org/10.1021/jf902107d

Serafini, M., Ghiselli, A., \& Ferro-Luzzo, A. (1996). In vivo antioxidant effect of green and black tea in man. European Journal of Clinical Nutrition, 50(1), 28-32. 
Serafini M., Laranjinha, J., Almeida, L., \& Maiani, G. (2000). Inhibition of human LDL lipid peroxidation by phenol-rich beverages and their impact on plasma total antioxidant capacity in humans. The Journal of Nutrition Biochemistry, 11(11-12), 585-590. http://dx.doi.org/10.1016/S0955-2863(00)00124-8

Shahrzad, S., \& Bitsch, I. (1998). Determination of gallic acid and its metabolites in human plasma and urine by high-performance liquid chromatography. Journal of Chromatography B: Biomedical Sciences and Applications, 705(1), 87-95. http://dx.doi.org/10.1016/S0378-4347(97)00487-8

Spencer, J. P. E. Metabolism of tea flavonoids in the gastrointestinal tract. (2003). Journal of Nutrition, 133, 3255S-3261S

Stalmach, A., Mullen, W., Steiling, H., Williamson, G., \& Crozier, A. (2010). Absorption, metabolism, and excretion of green tea flavan-3-ols in humans with an ileostomy. Molecular Nutrition \& Food Research, 54(3), 323-334. http://dx.doi.org/10.1002/mnfr.200900194

Stalmach, A., Troufflard, S., Serafini, M., \& Crozier, A. (2009). Absorption, metabolism and excretion of Choladi green tea flavan-3-ols by humans. Molecular Nutrition \& Food Research, 53(1), S44-S53. http://dx.doi.org/10.1002/mnfr.200800169.

Sun T., Ho C.-T., \& Shahidi F. (2009). Bioavailability and metabolism of tea catechins in human subjects. In: Tea and Tea Products. Chemistry and Health - Promoting Properties. Ed. by Ho C.-T., Lin J.- K., Shahidi F. CRC Press. Taylor and Francis Group, Boca Raton, London, New York, 111-129.

Sung, H., Nah, J., Chun, S., Park, H., Yang, S., \& Min, W. (2000). In vivo antioxidant effect of green tea. European Journal of Clinical Nutrition, 54(7), 527-529. http://dx.doi.org/10.1038/sj.ejcn.1600994

Takino, M., Daishima, S., Yamaguchi, K., \& Nakahara, T. (2003). Quantitative liquid chromatography-mass spectrometry determination of catechins in human plasma by automated on-line extraction using turbulent flow chromatography. Analyst, 128, 46-50. http://dx.doi.org/10.1039/B209675G

Tsuchiya, H., Sato, M., Kato, H., Okubo, T., Juneja, L. R., \& Kim, M. (1997). Simultaneous determination of catechins in human saliva by high-performance liquid chromatography. Journal of Chromatography B: Biomedical Sciences and Applications, 703(1-2), p. 253-258. http://dx.doi.org/10.1016/S0378-4347(97)00412-X

Umegaki, K., Sugisaws, A., Yamada, K., \& Higuchi, M. (2001). Analytical method of measuring tea catechins in human plasma by solid-phase extraction and HPLC with electrochemical detection. Journal of Nutritional Science and Vitaminology, 47(6), 402-408.

Unno, T., Sagesaka, Y. M., \& Kakuda, T. (2005). Analysis of tea catechins in human plasma by high performance liquid chromatography with solid-phase extraction. Journal of Agriculture and Food Chemistry, 53(26), 9885-9889. http://dx.doi.org/10.1021/jf0522199

Vaidyanathan, J. B., \& Walle, T. (2002). Glucuronidation and sulfation of tea flavonoid (-)-epicatechin by the human and rat enzymes. Drug Metabolism and Disposition, 30(8), 897-903. http://dx.doi.org/10.1124/dmd.30.8.897

Van het Hof, K. H., de Boer, H., Wiseman, S., Lien, N., Westrate, J., \& Tijburg, L. (1997). Consumption of green and black tea does not increase resistance of low-density lipoprotein to oxidation in humans. American Journal of Clinical Nutrition, 66, 1125-1132.

Van het Hof, K. H., Kivits, G., Weststrate, J., \& Tijburg, L. (1998). Bioavailability of catechins from tea: the effect of milk. European Journal of Clinical Nutrition, 52(5), 356-359.

Warden, B. A., Smith, L. S., Beecher, G. R., Balentine, D. A., \& Clevidence, B. A. (2001). Catechins are bioavailable in men and women drinking black tea throughout the day. Journal of Nutrition, 131(6), 1731-1737.

Wiseman, S., Mulder, T., \& Rietveld, A. (2001). Tea Flavonoids: Bioavailability in Vivo and effects on cell signaling pathways in vitro. Antioxidants and Redox Signaling, 3(6), 1009-1021. http://dx.doi.org/10.1089/152308601317203549

Yang, B., Arai, K., \& Kusu, F. (2000). Determination of catechins in human urine subsequent to tea ingestion by high-performance liquid chromatography with electrochemical detection. Analytical Biochemistry, 283(1), 77-82. http://dx.doi.org/10.1006/abio.2000.4624

Yang, C. S., Chung, J. Y., Yang, G., Chhabra, S., \& Lee, M-J. (2000). Tea and tea polyphenols in Cancer Prevention. Journal of Nutrition, 130, 472S-478S. 
Yang, C., Chen, L., Lee, M., Balentine, D., Kuo, M., \& Schantz, S. (1998). Blood and urine levels of tea catechins after ingestion of different amounts of green tea by human volunteers. Cancer Epidemiology, Biomarkers \& Prevention, 7, 351-354.

Yoshino, K., Suzuki, M., Sasaki, K., Miyase, T., \& Sano, M. (1999). Formation of antioxidants from (-)-epigallocatechin gallate in mild alkaline fluids, such as authentic intestinal juice and mouse plasma. The Journal of Nutritional Biochemistry, 10(4), 223-229. http://dx.doi.org/10.1016/S0955-2863(98)00103-X

Table 1. Antioxidant Activity (AA) of Human Plasma After Consumption of Different Quantities of Tea

\begin{tabular}{|c|c|c|c|}
\hline No. & Quantity of Consumed Tea & Increase of $\mathrm{AA}$ in \% & Reference \\
\hline 1 & $\begin{array}{l}300 \mathrm{ml} \text { of green tea } \\
300 \mathrm{ml} \text { of black tea }\end{array}$ & 40 & Serafini et al., 1996 \\
\hline 2 & $\begin{array}{l}900 \mathrm{ml} \text { of green tea per day for } 4 \\
\text { weeks }\end{array}$ & 3.5 & Van het Hof et al., 1997 \\
\hline 3 & $300 \mathrm{ml}$ of tea & 15 & Pietta et al., 1998a \\
\hline 4 & $400 \mathrm{ml}$ of tea catechins & 16 & Pietta et al., 1998b \\
\hline 5 & $300-400 \mathrm{ml}$ of green tea & $\begin{array}{c}\text { Increase in relation to water } \\
\text { consumption }\end{array}$ & Benzie et al., 1999 \\
\hline 6 & $\begin{array}{l}\text { Green tea } \\
150 \mathrm{ml} \\
300 \mathrm{ml} \\
45 \mathrm{ml}\end{array}$ & $\begin{array}{c}0 \\
7 \\
12 \\
\end{array}$ & Sung et al., 2000 \\
\hline 7 & $\begin{array}{l}300 \mathrm{ml} \text { of green tea } \\
300 \mathrm{ml} \text { of black tea }\end{array}$ & $\begin{array}{l}40 \\
52\end{array}$ & Serafini et al., 2000 \\
\hline 8 & $\begin{array}{l}1200 \mathrm{ml} \text { of black tea }(200 \mathrm{ml} \text { every } \\
\text { hour for } 6 \text { hours })\end{array}$ & $65-76$ & Longley-Evans, 2000 \\
\hline
\end{tabular}

Table 2. Determination of Catechins in Biological Fluids and Tissues of Humans and Animals

\begin{tabular}{ccc}
\hline No. & Type of Biological Fluid or Tissue & Reference \\
\hline 1. & Plasma & Ho et al., 1995; Kivits et al., 1997, Shahrzad and \\
& & $\begin{array}{c}\text { Bitsch, 1998; Umegaki et al., 2001; Takino et al., } \\
\text { 2003; Kotani et al., 2003; Unno et al., 2005; } \\
\text { Masukawa et al., 2006; El-Hady et al., 2008; } \\
\text { Stalmach et al., 2009 }\end{array}$ \\
\hline 2. & Serum & Kivits et al., 1997; El-Hady et al., 2008 \\
\hline 3. & Saliva & Tsuchiya et al., 1997 \\
\hline 4. & Urine & $\begin{array}{c}\text { Yang et al., 2000; Clifford et al, 2000; Manach et } \\
\text { al., 2005; Mulder et al., 2005; Auger et al., 2008; } \\
\end{array}$ \\
& Stalmach et al., 2009 \\
\hline 5. & Feces & Lee et al., 2006 \\
\hline 6. & Prostate cells & Henning et al., 2006 \\
\hline 7. & Brain & Rechner et al., 2001 \\
\hline 8. & Cancer cells & Kim et al., 2000 \\
\hline
\end{tabular}

Table 3. Bioavailability of Tea Catechins

\begin{tabular}{ccccc}
\hline No. & $\begin{array}{c}\text { Type of Tea or } \\
\text { Catechin }\end{array}$ & $\begin{array}{c}\text { Amount of Consumed } \\
\text { Catechins }\end{array}$ & $\begin{array}{c}\text { Amount of Catechins Found in } \\
\text { Blood Plasma }\end{array}$ & References \\
\hline 1. & Green Tea & $90-150 \mathrm{mg}$ & $0.1-0.7 \mu \mathrm{M} / \mathrm{g}$ & Clifford et al., 2000 \\
\hline 2. & Green Tea & $679 \mathrm{mg}$ & $1.3 \mu \mathrm{M} / \mathrm{g}$ & Nokagawa et al., 1999 \\
\hline 3. & Black Tea & $496 \mathrm{mg}$ & $0.5 \mu \mathrm{M} / \mathrm{g}$ & Manach et al., 2004 \\
\hline 4. & EGCG & $82 \mathrm{mg}$ & $1.22 \cdot 10^{-3} \mathrm{mg} / \mathrm{ml}$ & Clifford et al., 2000 \\
\hline
\end{tabular}

